\title{
EFEKTIVITAS MODEL PEMBELAJARAN ROLE PLAYING DALAM MENINGKATKAN PEMAHAMAN SISWA TERHADAP MATERI KISAH HIJRAH PADA MATA PELAJARAN PAI DI SMPN 7 BANDUNG
}

\author{
Yunus Yustian, * Abas Asyafah, dan Mokh. Iman Firmansyah \\ Universitas Pendidikan Indonesia \\ *E-mail:yunusyustian12@gmail.com
}

\begin{abstract}
This present study is primarily based on the low of activities and learning results of the students in class VIII SMP Negeri 7 Bandung on Islamic Education subject, particularly in story materials, which are caused by the implementation of inappropriate learning model. The design used in this carried out study was quasi experimental design using non-equivalent control group design. Then, the instruments used in this study were in the form of objective tests of cognitive domain using multiple choices question. In the process of data analysis, this study performed normality test, homogeneity test, normalized gain calculation, and t-test consisting of paired sample test and independent sample test. The results showed that there was a significant difference, in which the experimental class was considered to be better than the control class (2-tailed sig. value was 0.000). For further study, it is suggested that the collaborative learning model of role playing type can be applied in the field of Islamic Education subject aside from the story materials by considering the advantages and disadvantages of this model.
\end{abstract}

Keywords: Effectiveness, Collaborative Model of Role Playing Type, Student Understanding.

\begin{abstract}
ABSTRAK
Penelitian ini dilatarbelakangi rendahnya aktivitas dan hasil belajar siswa kelas VIII SMP Negeri 7 Bandung pada mata pelajaran PAI materi kisah, yang disebabkan kurang tepatnya model pembelajaran. Desain penelitian yang digunakan adalab kuasi eksperimen dengan bentuk nonequivalent control grup design. Instrumen yang digunakan berupa tes objektif ranah kognitif dengan bentuk soal piliban ganda. Analisis data meliputi uji normalitas, uji homogenitas, perbitungan gain ternormalisasi, uji t-test yang terdiri dari uji paired sample test dan uji independent sample test. Hasil penelitian menunjuk.kan terdapat perbedaan signifikan, dimana kelas eksperimen lebih baik daripada kelas kontrol (nilai sig. 2-tailed sebesar 0,000). Bagi peneliti selanjutnya agar model pembelajaran kolaboratif tipe role playing dapat diterapkan pada ruang lingkup PAI di luar materi kisah dengan memperhatikan kelebihan dan kekurangan model ini.
\end{abstract}

Kata Kunci: Efektivitas, Model Kolaboratif Tipe Role Playing, Pemahaman Siswa.

TARBAWY: Indonesian Journal of Islamic Education - Vol. 4 No. 2 (2017) | 126 


\section{PENDAHULUAN}

Guru dituntut kreatif dan inovatif dalam memilih dan menerapkan model pembelajaran. Sehingga dapat mengembangkan proses pembelajaran yang aktif dan menyenangkan. Model pembelajaran yang tepat dapat meningkatkan aktivitas dan hasil belajar siswa.

Aktivitas dan hasil belajar siswa akan meningkat apabila dalam penggunaan model pembelajaran sesuai dengan materi yang akan disampaikan. Sebagai contoh, beberapa guru mengajarkan materi kisah dengan metode ceramah. Sehingga dengan metode tersebut banyak siswa cenderung pasif, dan berpotensi tidak memahami materi yang disampaikan.

Penggunaan model pembelajaran yang tidak tepat diasumsikan karena kurangnya inovasi guru terhadap model pembelajaran. Sehingga harapan dan tujuan pendidikan tidak dapat tercapai sesuai dengan yang diharapkan.

Siswa kelas VIII SMP Negeri 7 Bandung memiliki aktivitas dan hasil belajar pada mata pelajaran PAI materi kisah yang rendah. Dari hasil identifikasi diperoleh bahwa belum optimalnya penggunaan model pembelajaran.

Berkaitan dengan hal tersebut, dilakukan penelitian dengan model pembelajaran kolaboratif tipe role playing. Fokus penelitian ini meliputi penguasaan awal kelas eksperimen dan kontrol sebelum pembelajaran, implementasi proses pembelajaran kolaboratif tipe role playing, penguasaan akhir kelas eksperimen dan kontrol dan efektivita model pembelajaran kolaboratif tipe role playing pada mata pelajaran PAI materi kisah.

Majid (2012, hlm. 127) secara umum model pembelajaran adalah kerangka konseptual dan prosedur yang sistematik dalam mengorganisasi pengalaman belajar untuk mencapai tujuan belajar tertentu, dan berfungsi sebagai pedoman bagi perancang pengajaran dan para guru dalam merencanakan dan melaksanakan aktivitas belajar mengajar. Sedangkan menurut Justi \& Gilbert (2002, hlm. 6) model pembelajaran adalah proses kompleks yang melibatkan banyak kegiatan, komponen, dan keterampilan yang harus dikuasai. Berbeda dengan pendapat tersebut, Gakhal \& Bull (2008, hlm.123) berpendapat bahwa model pembelajaran adalah representasi dari pengetahuan pembelajaran (keterampilan dan kompetensi).

Model pembelajaran terbagi menjadi dua macam yaitu model pembelajaran klasikal dan kolaboratif. Model pembelajaran klasikal yaitu model pembelajaran yang kita lihat sehari hari. Pada model ini guru mengajar sejumlah siswa, biasanya antara 30 sampai dengan 40 orang siswa di dalam sebuah ruangan. Sedangkan model pembelajaran kolaboratif adalah model pembelajaran yang memerlukan adanya elemenelemen yang merupakan bahan dasar agar pembelajaran tersebut dinamakan pembelajaran kolaboratif (Isjoni, 2007, hlm. 65-66). Sedangkan menurut Glass \& Putnam (1989, hlm. 47) Model 
pembelajaran kolaboratif adalah kegiatan pembelajaran yang menuntut siswa bekerja bersama-sama dalam beberapa kelompok heterogen untuk mencapai tujuan akademik seperti penyelesaian lembar kerja, tugas dan proyek.

Model pembelajaran kolaboratif, memiliki kelebihan diantaranya, menurut Manera \& Glockhamer (1988, hlm. 53) banyak pendidik mengakui bahwa pembelajaran kolaboratif meningkatkan retensi, meningkatkan kemampuan untuk mengartikan ide-ide, dan mengembangkan strategi penalaran yang lebih tinggi seperti analisis, evaluasi dan penerapan. Sedangkan menurut Isjoni (2007, hlm. 66) komunikasi dan interaksi memungkinkan terjadinya pertukaran informasi yang membantu meningkatkan pemikiran serta memberikan gagasan-gagasan baru dalam diri siswa. setiap siswa memiliki tanggung jawab serta pembagian tugas masing-masing. Menurut Slavin (2014, hlm. 5) menyatakan bahwa model ini mengacu pada metode pengajaran dimana siswa bekerja sama dalam kelompok-kelompok kecil untuk saling membantu dalam pembelajaran.

Salah satu model kolaboratif adalah model pembelajaran kolaboratif tipe role playing. Model pembelajaran kolaboratif tipe role playing adalah sejenis permainan gerak yang di dalamnya ada tujuan, aturan dan edutainment (Huda, 2013, hlm. 208-209). Osborn \& Costas (2013, hlm. 93) menambahkan role playing adalah teknik pedagogis digunakan secara teratur oleh konselor pendidik sebagai cara untuk memberikan konseling siswa kesempatan untuk berlatih microskills, menerapkan teori untuk berlatih, membangun keterampilan dan kepercayaan diri, pengalaman situasi konseling umum dan sulit, menerima umpan balik yang konstruktif dalam lingkungan yang aman, dan menunjukkan peningkatan. Kelemahan pada model ini menurut Fessenden (1950, hlm. 23) model ini membutuhkan perencanaan persiapan yang benar-benar lama dan matang sehingga akan menghabiskan waktu. Sedangkan kelebihan model ini menurut Gordon (2014, hlm. 3) yaitu dapat menantang dan merangsang pemikiran ide siswa sehingga siswa menjadi lebih aktif.

Adapun langkah-langkah role playing adalah guru menyiapkan skenario yang akan ditampilkan, guru menunjuk beberapa siswa untuk mempelajari skenario dalam waktu beberapa hari sebelum pelaksanaan kegiatan belajar mengajar, guru membentuk kelompok siswa yang masing-masing beranggotakan 5 orang, guru memberikan penjelasan tentang kompetensi yang ingin dicapai, guru memanggil para siswa yang sudah ditunjuk unuk melakonkan skenario yang sudah dipersiapkan, masingmasing siswa berada di kelompoknya sambil mengamati skenario yang sedang diperagakan, setelah selesai ditampilkan, masing-masing siswa diberikan lembar kerja untuk membahas/memberi penilaian atas

TARBAWY: Indonesian Journal of Islamic Education - Vol. 4 No. 2 (2017) | 128 
penampilan masing-masing kelompok, masing-masing kelompok menyampaikan hasil kesimpulannya, dan terakhir guru memberikan kesimpulan dan evaluasi secara umum. (Huda, 2013, hlm. 211)

Penggunaan model pembelajaran kolaboratif tipe role playing, diharapkan mampu membantu tercapainya tujuan pembelajaran. Indikator keberhasilan belajar siswa yang harus tercapai antara lain ranah kognitif afektif maupun psikomotor siswa. Ketiga ranah tersebut dapat tercapai dalam proses pembelajaran. Sebagaimana menurut Rao \& Stupans (2012, hlm. 427) bahwa role playing dapat digunakan diberbagai bidang disiplin untuk mengatasi ranah kognitif, psikomotorik dan afektif. Menurut Presscott (1990, hlm. 33) bahwa evaluasi model pembelajaran kolaboatif dapat dilakukan dengan cara melihat apakah siswa merefleksikan dirinya dengan baik dan dapat bekerjasama dalam kelompok.

Pada hakikatnya dengan proses pembelajaran seorang individu memiliki potensi untuk merubah tingkah lakunya ke arah yang lebih baik. Menurut Ramayulis (2008, hlm. 235) bahwa perubahan tingkah laku sebagai hasil belajar tersebut relatif tetap dan bukan hanya perubahan yang bersifat sementara. lainnya.

Perubahan tingkah laku tersebut tentunya berawal dari pemahaman belajar. Sebagaimana menurut
Sudijono (2011, hlm. 50) pemahaman (comprehension) adalah kemampuan seseorang mengerti atau memahami sesuatu setelah sesuatu itu diketahui dan diingat. Dengan kata lain, memahami adalah mengetahui tentang sesuatu dan dapat melihatnya dari berbagai segi. Pemahaman belajar siswa adalah proses dimana siswa dapat memahami suatu keadaan yang ia jalani saat pembelajaran.

\section{METODE PENELITIAN}

Metode yang digunakan dalam penelitian ini adalah eksperimen dengan pendekatan kuantitatif. Dalam pengumpulan datanya menggunakan instrument penelitian, pengolahan datanya berupa angka-angka dan dianalisis menggunakan statistik. Menurut Darwis (2014, hlm. 12) penelitian kuantitatif menghasilkan data yang berbentuk angka atau data kualitatif yang diangkakan/scoring. Pendekatan kuantitatif dalam penelitian ini digunakan untuk memperoleh data tentang keefektivitasan model pembelajaran role playing dalam meningkatkan pemahaman siswa tehadap materi kisah hijrah pada mata pelajaran pendidikan agama Islam.

Salah satu metode dalam penelitian kuantitatif adalah metode penelitian eksperimen. Penelitian eksperimen dilakukan untuk mencari pengaruh perlakuan dalam kondisi yang dikendalikan. Menurut Ali (2010, 
hlm. 84) eksperimen adalah riset yang dilaksanakan melalui eksperimentasi atau percobaan. Eksperimen menunjukkan kepada suatu upaya sengaja dalam memodifikasi kondisi yang menentukan munculnya suatu peristiwa, serta pengamatan dan interpretasi perubahan-perubahan yang terjadi pada peristiwa itu yang dilakukan secara terkontrol. Sedangkan eksperimen yang dilakukan dalam penelitian ini adalah kuasi eksperimen. Menurut Ali (2010, hlm. 101) perbedaan utama eksperimen (sejati) dan kuasi eksperimen terletak pada pemilihan subjek sampel secara random dan penugasan subjek secara random. Dalam pemilihan subjek pada eksperimen, perandoman dilakukan terhadap setiap individu subjek anggota populasi. Selanjutnya, setelah diperoleh sekelompok subjek sebagai sampel dilakukan penugasan secara random untuk memecah sampel itu menjadi dua kelompok, yaitu kelompok ekperimen dan kelompok kontrol. Apabila dicermati secara lebih teliti, cara seperti ini berpotensi mencerabut subjek-subjek sampel itu dari situasi lingkungan alamiahnya, sehingga berbagai fenomena yang dapat dijumpai dalam pelaksanaan studi berpotensi artifisial atau bersifat tidak alami. Mengingat kondisi seperti ini dapat digunakan alternatif pelaksanaan penelitian yaitu dengan Kuasi-eksperimen.

Desain yang dipakai pada penelitian ini menggunakan penelitian Quasi eksperimental design dalam pengambilan sampelnya tidak diambil secara random dari populasi yang telah tersedia, akan tetapi ditentukan dalam pengambilan sampelnya. Dalam penelitian Quasi Eksperimental dengan bentuk non-equivalent control group design ini, kedua sampel harus dibuat sama (homogen). Oleh karena itu, peneliti melakukan uji homogenitas untuk mengetahui'apakah kedua kelompok kelas yang diambil memiliki kondisi yang sama atau tidak selain itu dilakukan juga uji normalitas

Penelitian ini menggunakan instrumen berupa tes objektif menyangkut ranah kognitif dengan bentuk soal pilihan ganda. Responden diberikan pilihan a, b, c, dan d dalam setiap pertanyaan untuk menjawab instrumen tersebut. Pembuatan soal dibuat oleh peneliti berdasarkan kurikulum KTSP. Sedangkan soal yang dijadikan sebagai pre-test dan post-test berjumlah 40 soal.

\section{HASIL PENELITIAN DAN PEMBAHASAN}

\section{Penguasaan Awal Siswa Terhadap Materi Kisah}

a. Penguasaan Awal Siswa kelas Eksperimen

Sebelum melakukan pembelajaran pada materi ini, peneliti melakukan pretest terlebih dahulu untuk mengetahui penguasaan awal siswa. Setelah melakukan pretest diketahui penguasaan awal siswa pada kelas eksperimen bahwa tidak ada siswa yang memiliki kategori nilai sangat 
baik. Kategori nilai baik ada 22\% siswa dari jumlah seluruh siswa yang mengikuti pretest di kelas eksperimen. Kemudian untuk siswa yang memiliki kategori nilai cukup ada $16 \%$ siswa dari jumlah seluruh siswa yang mengikuti pretest di kelas eksperimen. Sedangkan untuk siswa yang memiliki kategori nilai kurang ada $62 \%$ siswa dari jumlah seluruh siswa yang mengikuti pretest di kelas eksperimen. Sementara itu, tidak ada siswa yang memiliki kategori nilai sangat baik pada pretest di kelas eksperimen.

Kemudian sesuai hasil perhitungan, sebanyak $44 \%$ siswa kelas eksperimen memahami materi ini. Adapun uraiannya yaitu dari 5 indikator pada bab ini, indikator kesatu sebesar 49\%, indikator kedua sebesar $41 \%$, indikator ketiga sebesar 35\%, indikator keempat sebesar $47 \%$, dan indikator kelima sebesar $47 \%$.

Berdasar data di atas, jumlah siswa yang memiliki kategori nilai kurang lebih banyak dibandingkan siswa yang memiliki kategori nilai baik dan cukup. Hal ini menunjukkan bahwa sebagian besar siswa belum mengetahui dan memahami materi yang akan dipelajari. Sebagaimana menurut Sudijono (2011, hlm. 50) bahwa pemahaman (comprehension) merupakan kemampuan seseorang mengerti atau memahami sesuatu setelah sesuatu itu diketahui dan diingat. Pemahaman belajar siswa adalah proses dimana siswa dapat memahami suatu keadaan yang ia jalani saat pembelajaran. Mengacu pada pendapat tersebut, banyaknya siswa yang memiliki kategori nilai kurang dikarenakan siswa belum mempelajari materi yang diteskan. Sehingga hal yang diperlukan ketika siswa belum memahami materi yang diteskan adalah dengan proses pembelajaran yang efektif.

Pada hakikatnya dengan proses belajar mengajar seorang individu memiliki potensi untuk merubah tingkah lakunya ke arah yang lebih baik. Namun hal tersebut dibutuhkan beberapa usaha pula dari siswa sebagaimana menurut Ramayulis (2008, hlm. 235) bahwa perubahan tingkah laku sebagai hasil belajar dapat terjadi melalui usaha mendengar, membaca mengikuti petunjuk, mengamati, memikirkan, menghayati, meniru dan melatih dengan pengajaran dan pelatihan. Adapun perubahan tingkah laku sebagai hasil belajar tersebut relatif tetap dan bukan hanya perubahan yang bersifat sementara. Tingkah laku mengalami perubahan menyangkut semua aspek kepribadian, baik perubahan pengetahuan, kemampuan keterampilan, kebiasaan, sikap dan aspek perilaku lainnya.

TARBAWY: Indonesian Journal of Islamic Education - Vol. 4 No. 2 (2017) $\mid \mathbf{1 3 1}$ 


\section{b. Penguasaan Awal Siswa Kelas Kontrol}

Penguasaan awal siswa kelas kontrol diketahui bahwa tidak ada siswa yang memiliki kategori nilai sangat baik. Siswa baik ada 31,25\% siswa dari jumlah seluruh siswa yang mengikuti pretest di kelas kontrol. Kemudian untuk siswa yang memiliki kategori nilai cukup ada $31,25 \%$ siswa dari jumlah seluruh siswa yang mengikuti pretest di kelas kontrol. Sedangkan untuk siswa yang memiliki kategori nilai kurang ada 37,5\% siswa dari jumlah seluruh siswa yang mengikuti pretest di kelas kontrol.

Sesuai hasil perhitungan, sebanyak 50\% siswa kelas kontrol memahami materi ini. Adapun uraiannya yaitu dari 5 indikator pada bab ini, indikator kesatu sebesar 52\%, indikator kedua sebesar 34\%, indikator ketiga sebesar $43 \%$, indikator keempat sebesar $62 \%$, dan indikator kelima sebesar $58 \%$.

Berdasar data di atas, jumlah siswa yang memiliki kategori nilai baik, cukup dan kurang hampir merata. Hal ini menunjukkan bahwa setiap siswa di kelas kontrol memiliki nilai yang beragam. Keberagaman penguasaan awal siswa dapat dipengaruhi oleh beberapa faktor yang mempengaruhi proses belajarnya. Menurut Sopiatin (2011, hlm. 69) faktor yang mempengaruhi proses belajar antara lain: kurikulum atau bahan pelajaran, guru, sarana dan fasilitas, serta manajemen yang berlaku di sekolah tersebut. Dalam keseluruhan sistem inilah yang menentukan, bagaimana proses belajar mengajar dapat terjadi di dalam diri siswa.

c. Perbandingan Rerata Antara Nilai Pretest Kelas Eksperimen dan Kontrol Sebelum Dilakukan Pembelajaran

Setelah dilakukan uji Independent sample t-test diperoleh bahwa nilai sig. (2-tailed) sebesar $0,029<0,05$. Berdasar ketentuan kriteria pengujian hipotesis dalam pengujian independent sample t-test jika signifikasi atau $t_{\text {hitung }}<0,05$ maka $H_{o}$ ditolak dan $H_{a}$ diterima.

Dengan demikian, terdapat perbedaan signifikan antara nilai rata-rata pretest kelas eksperimen dan kelas kontrol. Hal ini menunjukkan bahwa siswa kelas eksperimen dan kelas kontrol memiliki pemahaman yang relatif berbeda sebelum treatment dilakukan pada penelitian.

Data di atas menunjukkan bahwa penguasaan awal siswa eksperimen dan kontrol berbeda. Menurut Ramayulis (2008, hlm. 248) adanya perbedaan individual menunjukkan pula adanya perbedaan kondisi belajar setiap orang., agar setiap individu dapat berkembang optimal dalam proses belajar dipelukan orientasi yang paralel dengan kondisi yang dimilikinya; dituntut penghargaan guru akan individualitas. 
Menurut Ramayulis (2008, hlm. 248) untuk memenuhi prinsip perbedaan ada dua macam pendekatan yaitu pendekatan pertama menitikberatkan kepada pengajaran individual untuk memenuhi kebutuhan individu dan belajar kelompok hanya merupakan pelengkap untuk sosialisasi. Sebaliknya pendekatan kedua berusaha memenuhi perbedaan individu dengan mengorganisi kegiatan-kegiatan belajar yang perlu bagi murid dalam hubungannya dengan kegiatan kelompok.

\section{Gambaran}

Proses

Pembelajaran

Kelas

Eksperimen

Pada proses pembelajaran kelas eksperimen dan kelas kontrol terdapat perbedaan dari model pembelajarannya.

Model pembelajaran pada kelas kontrol memakai model student facilitator and explaining. Sedangkan pada kelas eksperimen peneliti menggunakan model role playing.

Proses pembelajaran kelas eksperimen di antaranya siswa dibagi menjadi lima kelompok, setiap kelompok mempelajari skenario yang telah diberikan, guru memberikan penjelasan tentang kompetensi yang ingin dicapai, guru memanggil para siswa yang sudah mempelajari skenario unuk melakonkan skenario yang sudah dipersiapkan, sedangkan kelompok siswa lain mengamati skenario yang sedang diperagakan, setelah selesai ditampilkan, masing-masing siswa diberikan lembar kerja untuk memberi penilaian atas penampilan masing-masing kelompok yang telah tampil, kemudian masingmasing kelompok menyampaikan hasil kesimpulannya.

.Model pembelajaran ini memiliki beberapa keunggulan dibandingkan dengan model lain di antaranya dapat memberikan kesan pembelajaran yang kuat dan tahan lama dalam ingatan siswa, dapat menjadi pengalaman belajar menyenangkan yang sulit untuk dilupakan, membuat suasana kelas menjadi lebih dinamis dan antusiastis, membangkitkan gairah dan semangat optimisme dalam diri siswa serta menumbuhkan rasa kebersamaan, memungkinkan siswa untuk terjun langsung memerankan sesuatu yang akan dibahas dalam proses belajar Proses pembelajaran pun menjadi sangat menyenangkan, karena siswa dituntut aktif berperan dalam proses pembelajaran ini, khususnya pembelajaran tentang materi kisah. Sedangkan kekurangan model pembelajaran ini antara lain banyaknya waktu yang dibutuhkan, kesulitan menugaskan peran tertentu kepada siswa jika tidak dilatih dengan baik, ketidakmungkinan menerapkan role playing jika suasana kelas tidak

TARBAWY: Indonesian Journal of Islamic Education - Vol. 4 No. 2 (2017) | 133 
kondusif, membutuhkan persiapan yang benar-benar matang yang akan menghabiskan waktu dan tenaga, dan tidak semua materi pelajaran dapat disajikan melalui strategi ini (Huda, 2013, hlm. 209-211).

\section{Penguasaan Akhir Siswa Terhadap Materi Kisah \\ a. Penguasaan Siswa Kelas Eksperimen dan Kontrol Setelah Melakukan \\ Pembelajaran}

Penguasaan akhir siswa pada kelas eksperimen diketahui bahwa siswa yang memiliki kategori nilai sangat baik ada 3\% siswa dari jumlah seluruh siswa yang mengikuti di kelas eksperimen. Siswa yang termasuk kategori nilai baik ada 94\% siswa. Kemudian untuk siswa yang termasuk kategori nilai cukup ada $3 \%$ dari jumlah seluruh siswa yang mengikuti post-test di kelas eksperimen. Sedangkan tidak ada siswa yang termasuk kategori nilai kurang dari jumlah seluruh siswa yang mengikuti post-test di kelas eksperimen.

Sesuai hasil perhitungan, sebanyak $67 \%$ siswa kelas eksperimen memahami materi ini. Adapun uraiannya yaitu dari 5 indikator pada bab ini, indikator kesatu sebesar 69\%, indikator kedua sebesar $65 \%$, indikator ketiga sebesar 66\%, indikator keempat sebesar 69\%, dan indikator kelima sebesar $66 \%$.
Sedangkan penguasaan akhir siswa pada kelas kontrol diketahui bahwa siswa yang termasuk kategori nilai baik ada $97 \%$ siswa dari jumlah seluruh siswa yang mengikuti posttest di kelas eksperimen. Sedangkan untuk siswa yang termasuk kategori nilai kurang ada 3\% dari jumlah seluruh siswa yang mengikuti post-test di kelas kontrol.

Sesuai hasil perhitungan, sebanyak 67\% siswa kelas kontrol memahami materi ini. Adapun uraiannya yaitu dari 5 indikator pada bab ini, indikator kesatu sebesar $58 \%$, indikator kedua sebesar 55\%, indikator ketiga sebesar $74 \%$, indikator keempat sebesar $76 \%$, dan indikator kelima sebesar $73 \%$.

Perbedaan peningkatan penguasaan pembelajaran di atas tidak terlepas dari proses pembelajarannya yang berpengaruh. Peneliti melihat salah satu hal yang berpengaruh yaitu model pembelajaran yang digunakan. Menurut Majid (2012, hlm. 127) secara umum model diartikan sebagai kerangka konseptual yang digunakan sebagai pedoman dalam melakukan suatu kegiatan. Atas dasar pemikiran tersebut, maka yang dimaksud dengan model pembelajaran adalah kerangka konseptual dan prosedur yang sistematik dalam mengorganisasi pengalaman belajar untuk mencapai tujuan belajar tertentu,

TARBAWY: Indonesian Journal of Islamic Education - Vol. 4 No. 2 (2017) | 134 
dan berfungsi sebagai pedoman bagi perancang pengajaran dan para guru dalam merencanakan dan melaksanakan aktivitas belajar mengajar.

Menurut Ramayulis (2008, hlm. 185) bahwa dalam pemilihan metode, pendidik harus memperhatikan dasar-dasar umum metode pendidikan Islam. Metode yang tepat dalam mendidik siswanya adalah dengan menyesuaikan metode ddengan kondisi psikis siswanya ia harus mengusahakan agar materi pelajaran yang diberikan siswa mudah diterima.

Peneliti menggunakan model pembelajaran ini karena dengan model pembelajaran ini, materi pelajaran akan mudah diterima terkhusus untuk materi kisah. Terbukti dengan menggunakan model ini, penguasaan awal siswa eksperimen $\gg$ mengalami peningkatan.

b. Peningkatan Penguasaan Siswa Terhadap Materi Kelas Eksperimen dan Kontrol Setelah Melakukan Pembelajaran

Peningkatan pemahaman siswa setelah pembelajaran dengan menggunakan model pembelajaran role playing dihitung dengan menggunakan rata-rata gain ternormalisasi. Berdasarkan perhitungan, rata-rata gain ternormalisasi dari kelas eksperimen adala 0,58. Dengan sig.(2-tailed) $\quad 0,000 \quad, \quad 0,05$ menunjukan peningkatan yang terjadi tersebut signifikan.

Sementara untuk rata-rata gain ternormalisasi dari kelas kontrol adalah -0,40. Dengan sig.(2-tailed) $0,012<0,05$ menunjukkan peningkatan yang terjadi tersebut signifikan. Dengan demikian, kelas eksperimen dan kelas kontrol sama-sama mengalami peningkatan pemahaman setelah proses pembelajaran dilakukan. Hal ini membuktikan bahwa pemahaman siswa dapat berkembang seiring dengan pendapat dari Sudijono (2011, hlm. 50) bahwa pemahaman (comprehension) merupakan kemampuan seseorang mengerti atau memahami sesuatu setelah sesuatu itu diketahui dan diingat.

Peningkatan penguasaan siswa pada hakikatnya merupakan salah satu tujuan dari adanya pembelajaran karena setiap siswa dapat merealisasikan sebuah potensi yang terdapat pada dirinya dengan belajarr, karena menuut menurut Ramayulis (2008, hlm. 242) belajar yang berhasil telah melalui berbagai macam aktivitas, baik aktivitas fisik maupun psikis.

TARBAWY: Indonesian Journal of Islamic Education - Vol. 4 No. 2 (2017) $\mid 135$ 
Seluruh peranan dan kemauan dikerahkan dan diarahkan supaya daya itu tetap aktif untuk mendapat hasil pembelajaran yang optimal, sekaligus mengikuti proses pengajaran secara aktif.

\section{Efektivitas Penggunaan} Model Pembelajaran Role Playing Dalam Meningkatkan Pemahaman Siswa Pada Mata Pelajaran PAI

Dari perhitungan yang telah dilakukan sebelumnya, bahwa telah dirumusan hipotessis untuk mengetahui efektif atau tidaknya model ini, maka peneliti melakukan pengujian hipotesis dengan menggunakan uji independent sample test, dengan diketahui terlebih dahulu rerata nilai gain kelas eksperimen yaitu 0,58 dan rerata nilai gain kelas kontrol -0,40. Hal ini menunjukkan bahwa rerata nilai gain kelas eksperimn lebih besar dari pada rerata nilai gain kelas kontrol.

Berdasarkan hasil data gain kelas eksperimen dan kelas kontrol dengan menggunakan uji independent sample test, diperoleh bahwa data tidak homogen sehingga nilai yang dilihat adalah nilai equal variances not asuumed, diketahui nilai sig. (2-tailed) sebesar 0,000 lebih kecil dari 0,05. Berdasar ketentuan di bab III, jika sig. (2tailed) $<0,05$ maka $H_{o}$ ditolak dan $\mathrm{H}_{\mathrm{a}}$ diterima, atau dengan kata lain rata-rata gain siswa yang melakukan pembelajaran dengan menggunakan model pembelajaran role playing dengan siswa yang tidak menggunakan model pembelajaran role playing dalam meningkatkan pemahaman siswa pada pembelajaran PAI adalah berbeda. Maka diketahui bahwa perbedaan yang cukup signifikan antara rerata nilai gain kelas eksperimen dan rerata nilai kelas kontrol, dan dapat diambil kesimpulan bahwasannya model role playing ini efektif dalam meningkatkan pemahaman siswa pada materi kisah.

Dari keberhasilan pengajaran tersebut tidak akan lepas dari proses belajarnya. Hal ini didukung oleh pendapat Sudjana (1990, hlm. 65) bahwa hasil belajar pada dasarnya merupakan akibat dari suatu proses belajar. Ini berarti bahwa optimalnya hasil belajar siswa tergantung pada proses belajarnya. Proses pembelajaran dengan menggunakan model pembelajaran role playing yang efektif untuk materi kisah, bisa jadi dikarenakan sebagaimana menurut Huda (2013, hlm. 211) bahwa dengan model pembelajaran role playing pembelajaran ini dapat memberikan kesan pembelajaran yang kuat dan tahan lama dalam ingatan siswa karena proses pembelajaran sangat menyenangkan dan sulit untuk dilupakan. Proses pembelajaran yang berkesan akan membuat siswa memahami materi yang dijelaskan karena menurut Nasution (1992, hlm. 42) bahwa apabila siswa tidak dapat memahami apa yang disampaikan oleh guru, maka besar kemungkinan siswa tidak

TARBAWY: Indonesian Journal of Islamic Education - Vol. 4 No. 2 (2017) | 136 
dapat menguasai mata pelajaran yang diajarkan.

Oleh karena itu keterkaitan hasil belajar tidak akan pernah lepas dari proses pembelajaran yang dilakukan. Apabila proses pembelajarannya dilakukan dengan baik, maka akan baik pula hasilnya. Sebaliknya, apabila proses pembelajarannya dilakukan dengan kurang baik, maka akan kurang baik pula hasilnya.

\section{KESIMPULAN}

Berdasarkan penelitian tersebut dapat disimpulkan bahwa model pembelajaran kolaboratif tipe role playing efektif dalam meningkatkan pemahaman siswa pada materi kisah, tepatnya sebesar $0,000<0,05$. Terdapat perbedaan yang signifikan antara siswa yang melakukan pembelajaran dengan menggunakan model pembelajaran kolaboratif tipe role playing dengan siswa yang tidak menggunakan model pembelajaran kolaboratif tipe role playing.

Efektivitas model pembelajaran kolaboratif tipe role playing pun dapat terlihat dari kondisi awal dan akhir pemahaman siswa kelas eksperimen. Penguasaan rerata akhir siswa pada kelas eksperimen adalah 33,44 (baik), meningkat dari kondisi awalnya yakni 22,06 (kurang). Dengan demikian, model pembelajaran kolaboratif tipe role playing dapat diterapkan pada ruang lingkup PAI pada materi kisah yang tentunya dapat memperhatikan kelebihan dan kekurangan model ini.

Rekomendasi dari penelitian ini adalah penerapan model pembelajaran kolaboratif tipe role playing pada ruang lingkup PAI di luar materi kisah yang tentunya dapat memperhatikan kelebihan dan kekurangan model ini. Selain itu, diperlukan penelitian pembelajaran PAI dengan model pembelajaran kolaboratif lainnya. Dari perbandingan tersebut mampu meningkatkan pemahaman siswa dalam proses pembelajaran PAI.

\section{REFERENSI}

Ali, M. (2010). Metodologi dan Aplikasi Riset Pendidikan. Bandung: Pustaka Cendekia Utama.

Asyafah, A. (2014). Research based intruction in the teaching of islamic education. SpringerPlus a SpringerOpen Journal, 755(3), 1-5. (2014). The Method of Tadabur Qur'an: What Are the Student Views. International Education Studies, 7(6), 98-105.

Darwis, A. (2014). Metode Penelitian Pendidikan Islam. Jakarta: PT Rajagrafindo Persada.

Fessenden, S. (1950). Role playing plays a role in group dynamics. Western Speech, 14(1), 22-25.

TARBAWY: Indonesian Journal of Islamic Education - Vol. 4 No. 2 (2017) $\mid 137$ 
https://doi.org/10.1080/105703 15009373399

Gakhal, I., \& Bull, S. (2008). An open learner model for trainee pilots. Research in Learning Technology, 16(2), 123-135. https://doi.org/10.1080/096877 60802318436

Glass, R. M., \& Putnam, J. (1989). Cooperative Learning in Teacher Education: A Case Study. Action in Teacher Education, 10(4), 47-52. https://doi.org/10.1080/016266 20.1988.10519420

Gordon. (2014). Dramatherapy. Persona and Role Playing, I(December), 1-5. https://doi.org/10.1080/026306 72.1978 .9689123

Huda, M. (2013). Model-Model Pengajaran dan Pembelajaran. Yogyakarta: Pustaka Pelajar. Isjoni. (2007). Pembelajaran Visioner. Yogyakarta: Pustaka Pelajar.

Justi, R. S., \& Gilbert, J. K. (2002). Modelling, teachers' views on the nature of modelling, and implications for the education of modellers. International Journal of Science Education, 24(4), 369-387. https://doi.org/10.1080/095006 90110110142

Majid, A. (2012). Belajar dan Pembelajaran Pendidikan Agama Islam. Bandung: Remaja Rosdakarya.
Manera, E. S., \& Glockhamer, H. (1988). Cooperative Learning: Do Students "Own" The Content? Action in Teacher Education, 10(4), 53-56. https://doi.org/10.1080/016266 20.1988.10519421

Nasution, S. (1992). Berbagai Pendekatan dalam Proses Belajar Mengajar. Jakarta: Bumi Aksara.

Osborn, D., \& Costas, L. (2013). Creating Space For Connection: Creativity In The Classroom Role-Playing in Counselor Student Development. Journal of Creativity in Mental Health, 8(December 2014), 92-103. https://doi.org/10.1080/154013 83.2013 .763689

Prescott, S. (1990). Teachers Perceptions of Factors that Affect Successful Implementation of Cooperative Learning. Action in Teacher Education, 11(4), 30-34. https://doi.org/10.1080/016266 20.1990.10463098

Ramayulis. (2008). Ilmu Pendidikan Islam. Jakarta: Kalam Mulia.

Rao, D., \& Stupans, I. (2012). Exploring the potential of role play in higher education: development of a typology and teacher guidelines, 49(4), 427436.

Fessenden, S. (1950). Role- playing plays a role in group dynamics. Western Speech, 14(1), 22-25. 
https://doi.org/10.1080/105703 15009373399

Gakhal, I., \& Bull, S. (2008). An open learner model for trainee pilots. Research in Learning Technology, 16(2), 123-135. https://doi.org/10.1080/096877 60802318436

Glass, R. M., \& Putnam, J. (1989). Cooperative Learning in Teacher Education: A Case Study. Action in Teacher Education, 10(4), 47-52. https://doi.org/10.1080/016266 20.1988.10519420

Gordon. (2014). Dramatherapy. Persona and Role Playing, I(December), 1-5. https://doi.org/10.1080/026306 72.1978 .9689123

Justi, R. S., \& Gilbert, J. K. (2002). Modelling, teachers' views on the nature of modelling, and implications for the education of modellers. International Journal of Science Education, 24(4), 369-387. https://doi.org/10.1080/095006 90110110142

Manera, E. S., \& Glockhamer, H. (1988). Cooperative Learning: Do Students "Own" The Content? Action in Teacher Education, 10(4), 53-56. https://doi.org/10.1080/016266 20.1988.10519421
Osborn, D., \& Costas, L. (2013). Creating Space For Connection: Creativity In The Classroom Role-Playing in Counselor Student Development. Journal of Creativity in Mental Health, 8(December 2014), 92-103. https://doi.org/10.1080/154013 83.2013.763689

Prescott, S. (1990). Teachers Perceptions of Factors that Affect Successful Implementation of Cooperative Learning. Action in Teacher Education, 11(4), 30-34. https://doi.org/10.1080/016266 20.1990.10463098

Rao, D., \& Stupans, I. (2012). Exploring the potential of role play in higher education: development of a typology and teacher guidelines, 49(4), 427436.

Slavin, R. E. (2014). Cooperative learning in elementary schools. Education 3-13, 43(1), 5-14. https://doi.org/10.1080/030042 79.2015.963370

Sudijono, A. (2011). Pengantar Evaluasi Pendidikan. Jakarta: Rajawali Pers.

Sudjana, N. (1990). Penilaian Hasil Proses Belajar Mengajar. Bandung: PT Remaja Rosdakarya. 
